\title{
Priority areas to ensure sustainable development of educational exports of Russian universities in the context of digital transformation (regional aspect)
}

\author{
Olga Popova, Nafisa Gagarina, and Tatyana Minina \\ Ural State University of Economics, 8 Marta/Narodnoy Voli St. 62/45, 620144 Ekaterinburg, Russia
}

\begin{abstract}
The article considers digital technologies used to attract foreign students to regional universities. Forced distance learning during the pandemic COVID-19 revealed the weaknesses in the educational process when the need for intensive use of the existing digital technologies increased. This served as the basis for the active transformations of the priority areas in developing the digital environment in universities and the active use of online technologies to preserve the sustainable development of educational exports. With distant learning, the global competition for foreign students between universities only intensified making it necessary to create a high-quality digital environment. Russian universities used to compete with universities in other countries. But nowadays students can choose a university without leaving their homes. The main factors for their choice are the quality of education and reliability of the virtual infrastructure [1]. For the sustainable development of educational services exports, regional universities need to engage all the available digital tools to attract foreign applicants. They must position themselves as modern, internationally recognized educational institutions providing high quality education.
\end{abstract}

\section{Introduction}

The export of educational services is seen as one of the areas of development of Russian education, which is reflected in the National Project "Education" (valid since 01.01.2019 and planned for 5 years) [2]. The Federal Project "Export of Education" aims to double the number of foreign citizens studying at Russian universities [3]. At the same time, the Federal Project "Digital Educational Environment" was developed to create a modern and safe digital educational environment by 2024 , ensuring high quality and accessibility of education of all types and levels [4]. In addition, the Russian Federation has the "Strategy for the Development of Services Exports to 2025," [5] which defines the strategic measures for harmonizing Russian educational standards with foreign educational standards, increasing the rating of Russian universities, reducing the language barrier for foreign students, and ensuring a unified approach to the official sites of higher educational institutions on the Internet. 
The authors believe that to attract a foreign applicant, regional universities need to actively use the digital experience of the leading universities. The purpose of this article is to analyse the digital technologies used by two regional universities in Ekaterinburg to attract foreign applicants.

\section{Objectives}

1. Analyzing the factors affecting the choice of university by foreign applicants in Russia and the region.

2. Identifying the digital tools used by foreign students to search forthe information about universities.

3. Analyzing the digital tools used by regional universities to attract applicants.

The modern international education market is increasingly competing for talented foreign applicants. One of the criteria for choosing a university is its international rating. The university position in the ranking is important for foreign applicants. According to the QS (Quacquarelli Symonds) 2020 rating, the list of 100 best higher educational institutions in the world includes M.V. Lomonosov Moscow State University (84th place). Then there are Novosibirsk State University (231 place), St. Petersburg State University (234 place), Tomsk State University (268 place), Moscow State Technical University named after Bauman (284 place). Ural Federal University - UrFU occupying the 364 place [6].

Besides, a number of Russian higher education institutions are included in theinternational university rankings like QS (Quacquarelli Symonds), THE (Times Higher Education) and ARWU (Academic Ranking of World Universities).

The pandemic COVID-19 affected the strategies of universities for attracting and retaining foreign students. In particular, most universities started distant training. This process went together with some communication problems with students and dissatisfaction they felt.

Obviously, to solve the problem there is a need for a comfortable digital environment, which is necessary for universities in their further development. It should not be a formality or a temporary solution [7].

In June 2020, IPR-MEDIA conducted an anonymous survey of foreign students from more than 20 Russian universities in order to find out the main reasons for choosing a university and problem areas in studying at Russian universities [8].

When summarizing the answers to the question why they came to study in Russia, the following results were obtained (Table 1):

Table 1. Why did you come to study in Russia?

\begin{tabular}{|c|c|}
\hline Response rate \% & \% respondents \\
\hline Recognition of the Russian university diploma in my country & 39,5 \\
\hline Friendly environment & 15,8 \\
\hline Attractiveness of the country for various reasons & 10,5 \\
\hline Easier enrollment in the desired program compared to my country & 10,5 \\
\hline Migration benefits for foreign students & 7,9 \\
\hline
\end{tabular}

Thus, the main criterion for choosing a university is the recognition of the Russian university diploma in the applicant's country $(39,5 \%)$, the second important criterion is friendly environment $(15,8 \%)$. 
When asked about the reasons for choosing a Russian university the answers were distributed as follows (Table 2):

Table 2. Main reasons for choosing a Russian university*

\begin{tabular}{|c|c|}
\hline Response rate \% & \% respondents \\
\hline Attractiveness of the Russian education system & 57,5 \\
\hline Opportunity to learn the Russian language & 35,0 \\
\hline A number of popular educational programs and courses offered & 27,5 \\
\hline Mutual recognition of diplomas/qualifications between my country and Russia & 27,5 \\
\hline Recommendations from friends and acquaintances & 27,5 \\
\hline
\end{tabular}

*Students chose several options

The answers to the question about the reason for choosing a Russian university showed that the Russian education system attracts 57,5 foreign applicants. an opportunity to learn the Russian language is important for $35,0 \%$ of respondents. This shows that it is necessary to help foreign students to adapt to studying the subjects in Russian, providing them with all the opportunities for this. Universities should consider further employment opportunities for foreign students as some of them would like to make their career in the Russian Federation. [9].

The researchers also identified the reasons for choosing Russian universities as a higher education destination (Table 3 ).

Table 3. Main reasons for choosing a Russian university*

\begin{tabular}{|c|c|}
\hline Response rate \% & \% respondents \\
\hline Recommendations from friends and acquaintances & 40 \\
\hline Read reviews on the internet & 27,5 \\
\hline International university ranking & 22,5 \\
\hline The main factor is the city to studyin & 22,5 \\
\hline Looked at the site of the university & 20 \\
\hline
\end{tabular}

*Students chose several options

The main factor influencing the choice of the university is the recommendations of friends and acquaintances (40\%). $27.5 \%$ of foreign applicants read reviews on the Internet. In the third place are the international ranking of the university and the city to study in $(22.5 \%)$. For $20 \%$ of respondents the main reason for choosing the university is the university website. There are problems associated with the adaptation of the university official websites for foreign students [10]. In particular, not all educational institutions may have the English version of their site. At the same time, some foreign students may have difficulties with the Russian version of the site because of insufficient knowledge of the Russian language. However, the official pages in foreign languages that universities have in social networks are popular.

The research also revealed the negative sides. The most common problem foreign students experience in their adaptation is the difficulty of learning the Russian language. 
The learning material developed for Russian students is not suitable for foreign students. $[11,12]$.

In addition, one in five foreign students had an intention to leave the university in their first year of study. These were $22.5 \%$ of the respondents.

The authors think that with the pandemic the situation will hardly change for the better, as many universities are having problems with distance learning. Thus, instead of increasing their potential for developing educational services, some universities are at risk of losing a certain part of their student population.

\section{Results and discussion}

Within this study, the regional aspect of educational exports development is also of interest. The two largest universities of the Sverdlovsk region were chosen as the object of research because they carry out digital international activities: Federal State Autonomous Educational Institution of Higher Education «Ural Federal University named after the first President of Russia B.N.Yeltsin» (UrFU) and Federal State Budgetary Educational Institution of Higher Education «Ural State University of Economics» (USUE)

As of April 1, 2020, the number of foreign students at Ural Federal University was 4300 people from 110 countries of the world (as of April 1, 2019, there were 3807 foreign citizens from 78 countries of the world). UrFU is the leading university in training foreign students in the Ural region. According to the monitoring of the Russian universities' efficiency, the international activity indicator of the Ural Federal University is at $11.8 \%$ (in $2019-10.8 \%$ ) while the minimum threshold is $1 \%$ [13].

The university is recognized by foreign universities, it participates in international rankings QS, Times, Nimes Higher Education, Multibank, Webometrics. The university is strengthening its position in international professional associations ECPR, PCMD, EFMD, the University of the Arctic.

UrFU has 159 foreign graduate students, 40 foreign teachers from 40 countries of the world. The most attractive educational products of the university are 19 master 'programs and 41 postgraduate programs in the foreign language (English). In addition, 500 foreign universities from 62 countries of the world are the foreign partners of UrFU.

To promote UrFU in foreign markets, agreements were signed with the international news agency Russia Beyond the Headlines, information and advertising materials of the Ural Federal University are published in foreign languages (booklets, presentations, etc.), a new guide for foreign students was developed.

The second leading university in the Urals is USUE. In 2017-2018 academic year, there were 492 foreign students from 45 countries at the university. In 2018-2019 academic year, the university had 525 students from 50 countries of the world. As of April 1, 2020, 1168 foreign students from 56 countries were studying at the university. In 2007, the Ural State University of Economics entered the highest category of $\mathrm{H}+$ in the register of universities in Germany. The USUE diploma is recognized in European countries. In addition, the university is a full member of such international and regional associations as the Association "Eurasian Economic Club of Scientists", the Electronic Retailing Association (ERA), etc. An important fact confirming the university's focus on international cooperation is that the headquarters of the Association of Foreign Students of Russia operates in the Ural State University of Economics.

According to the monitoring of the Russian universities' efficiency, the international activity indicator of USUE is at $6.2 \%$ ((in $2019-4.44 \%$ ) while the minimum threshold is $1 \%[13]$.

The Ural State University of Economics has its Preparatory department for foreign citizens. In 2019-2020, 52 (in 2019 - 38) foreign students studied at USUE under exchange 
programs. In addition, since 2014, at USUE there has been working the Testing Centre for foreign citizens. Its main function is to help foreign citizens to improve their knowledge of the Russian language, Russian history and legislation. They help foreigners to adapt and be better prepared for employment and permanent residence in the Russian Federation. To help students to adapt to the new social, linguistic and cultural environment, the university organizes offsite events, visits to museums and iconic historical sites of Ekaterinburg and the Sverdlovsk region. Throughout their studies at the Preparatory department, students learn the Russian language in depth starting withzerolevel; they get acquainted with the traditions, culture and the specifics of life in Russia.

Both universities are actively working to attract foreign youth. UrFU has the English, Chinese, Spanish and Portuguese versions of their official website. In its turn, USUE has the English, Chinese, Spanish and French versions of their official website. The website pages for applicants provide the necessary information for international students. Universities actively promote themselves in social networks in the languages of Southeast Asia, China, India, the Middle East, Latin America and others.

To find out what sources of information about the university and the learning conditions were used by foreign applicants an online survey was conducted. The survey employed the Google form service. The General population was 5,468 students. The sample accounted for $5 \%$ of the total population, i.e. 274 international students. Among them: UrFU students - 215 people, USUE students - 59 people.

The survey participants were the citizens of Kazakhstan, Turkmenistan, Azerbaijan, Armenia, India, China, Italy, South Korea, Turkey, France, Mexico, Gambia, Zambia, Liberia, Sudan, Bulgaria, etc.

Based on the results of the online survey, the following conclusions were made.

First, the main reasons for choosing a university are as follows: recognition of the university diploma in the students 'country of origin (100\%), interest in Russia and the region where the University is located (92\%), exchange program participant $(4 \%)$, recommendations from relatives, friends and acquaintances $(32 \%)$, received a grant from the government of the Russian Federation (2\%). An interesting fact is that $13 \%$ of respondents are considering their future employment in the Ural region. These are mainly students from the CIS countrie sand China.

Second, $100 \%$ of respondents came to Ekaterinburg with some knowledge of the Russian language, but they were at different levels of language learning. The results revealed that students who decided to enter Russian universities purposefully study the Russian language long before coming to Russia, which indicates the selection ofa Russian University as an institution to study at. $78 \%$ of the survey participants had taken preparatory courses, and $85 \%$ attend additional Russian language courses while studying at the university.

Third, 91\% of students learned about Ekaterinburg from publications in the media, in particular through news coverage of the 2018 FIFA World Cup. According to the research done by «PR news» company, the frequency of mentioning Ekaterinburg in foreign media has increased by 7, 3 times since the beginning of the World Cup 2018. To compare, in May 2018, the world media wrote only 228 articles mentioning Ekaterinburg", whereas in June of the same year, there were already 1662 publications.

Fourth, 59\% of foreign students learnt about the Russian university when they attended the meeting with the university representatives visiting their country. $56 \%$ of respondents took interest in international cultural and sports events held in Ekaterinburg. $32 \%$ of the respondents learnt about the university in the Urals from relatives, friends and acquaintances. All $100 \%$ of the respondents searched for information about the Ural universities on the official websites of these universities and in social networks. 


\section{Conclusions}

The study of digital tools used by the two leading regional universities of the Sverdlovsk region in working with foreign students allowed the authors to draw the following conclusions.

Firstly, both regional universities are constantly working on improving their international rankings and they adapt their official websites to the needs of foreign students.

Secondly, the existing problem of learning Russian as a foreign language is being solved through additional language courses. During the pandemic, both universities switched to distance learning, which made it possible to retain the student population and continue training foreign students.

Thirdly, thanks to the systematic work on introducing digital technologies into the educational process, both universities managed to recruit foreign students for 2021 . The admission process continues. Nevertheless, we can already say that distance technologies have not reduced the interest of foreign students in learning at regional Russian universities.

The following aspects may be highlighted as recommendations: universities need to consider maintaining social networks in those foreign languages spoken in the source countries to attract foreign applicants. Pay more attention to the reviews of foreign students who graduated from Russian universities and post them on different sites on the Internet. Create more video content about successful foreign graduates. Show the learning and living conditions. Since the main factor determining the foreign students' successful adaptation and learning is the knowledge of Russian, teaching the Russian language should be transferred to the distance format both in preparatory and study periods.

Creating facilities and high-quality virtual environment to attractforeign students and providing them with educational services are currently becoming the main factors that allow developing the international brand of the university, increasing its competitiveness, as well as ensuring the sustainable development of educational exports in the medium term.

\section{References}

1. Y. Abdurazakova, Terra Econ., 11, 170 (2013)

2. Passport of National Project «Education», https://minobrnauki.gov.ru/

3. Passport of Priority Project «Development of Export Potential of the Russian System of Education», http://government.ru/

4. Passport of Federal Project «Digital Educational Environment», https://edu54.ru/

5. Order of Russian Federation Government of August 14, 2019 N1797-r(edit. of 20.06.2020) «On approval of the Strategy for the Development of Export of Services to 2025» (together with the "Action Plan for the Implementation of the Strategy for the Development of Exports of Services to 2025"), https://www.garant.ru/

6. University Rankings, https://www.topuniversities.com/

7. E. Zhadko, O. Popova, N. Gagarina, 16-th Intern. Conf. effic. and respons. in educat, 1737 (2019)

8. Analysis of the criteria for choosing a university by foreign students, https://iprmedia.ru/

9. A. Kirkwood, Pedag. and Educat., 18(2), 107 (2009)

10. O. Popova, N. Gagarina, D. Karkh, Adv. Soc. Sci. Educ. Hum. Res, 437, 738 (2020)

11. C. Marcelo-García, C. Yot-Domínguez, C. Mayor-Ruiz, Comunicar, 23(45), 117 (2015) 
12. C. Englund, A. Olofsson, L. Price, Higher Educat. Res. and Develop., 36(1), 73 (2017)

13. Information and analytical materials based on the results of monitoring the performance of educational institutions of higher education 2020, http://indicators.miccedu.ru/ 